\title{
Rip Van Winkle in Fiji
}

\author{
Adrian Mayer
}

The story of a person who falls asleep for many years and is then confronted with a changed society is one which exists in several cultures, most notably in Washington Irving's story of Rip van Winkle, who returns to his village in upstate New York after twenty years. Though I cannot claim to have been asleep, I recently returned to Fiji after an interval of some forty years. Hence, I can share in some of the astonishment that greeted Rip van Winkle and which he reciprocated among the inhabitants he met. I have been assured that this situation is worth recording, and so I make bold to share some impressions of my month's stay in Fiji in late 2010. This had come about because of a lunch which I had had earlier that year in London with Chris Gregory, a fellow anthropologist and Indianist, who had suggested that I revisit whilst he was able both to take me around and to contact people in the settlements before my arrival — it was an invitation too good to turn down.

First, I should reiterate that, in fact, my sleep had been rather longer than Rip's. I had first come to Fiji in August 1950 with my wife Kaia, and spent a year in the country, publishing an account of my stay entitled Peasants in the Pacific (1961). The 'peasants' in this title stemmed from a system of indenture under which some 60,000 Indians had been brought to Fiji between 1879 and 1916 to cultivate sugar cane. Many of these stayed after their indenture had ended, continuing to farm cane and constituting a major proportion of Fiji's population. My research centred on the question of what kind of community these people had formed in settlements which had grown up of people from different regions of India and with no previous ties of family or village. To answer this we lived in three settlements of cane farmers, two in Viti Levu and one in Vanua Levu. ${ }^{1}$

In 1971 I had returned to Fiji for two months, visiting two of these settlements in each of which I spent a fortnight, after which an enlarged edition of the book was published (1973). One might expect that a return in 2010 would mainly bring back memories of the more recent visit and that the earlier one would remain largely out of sight. But this would be to ignore the tendency of the old to retain memories of long duration over more recent impressions: and so I found that I mainly thought of the original visit, with the later one being largely out of sight. For instance, when I walked down Suva's Victoria Parade looking

1 Viti Levu and Vanua Levu are the largest and second-largest islands of the Fiji group. Ed. 
in vain for the Club Hotel, I remembered it as it was in 1950, wooden and with its wide upper veranda, rather than the 1971 concrete building erected after a cyclone had destroyed the old hotel.

But let me start at my arrival in Fiji in 2010. I note in my diary: 'After leaving Nadi, frame wooden houses, some on stilts, set among messy yards of broken material, or tidy gardens. Then a few patches of cane, some of tapioca, but much apparently fallow land, tangled vegetation and bits of jungle. Only near Suva and Navua are there neat rows of dalo. The gathering impression: Fiji is now much more like other such tropical places than it was. I saw only two bures between Nadi and Suva and even these were ceremonial'. Suva gave me a similar impression of convergence, as several comments attest: 'Suva is strange [to me], downtown is bustling with shops, malls, tall buildings and people in jeans, bula shirts and shorts if not miniskirts. Every now and then I come across a scene which superimposes itself on an earlier one - of frame buildings, empty streets, and the whiff of copra in the air. The present Suva seems incongruous, yet when I take it in I realise that this is the real Fiji and that I am here. Since this seems entirely improbable, both pictures have an air of unreality'. Again I note: 'Suva, like so many other places is now "globalised". Why not, this goes with a higher standard of life'. I was constantly comparing in my mind's eye, with such comments as: 'Through the residential area in Samabula. Funnily enough, it reminded me of Puerto Iguazú! [a town in northern Argentina]. Quite large and well maintained frame houses, lots of green shrubs around, a certain untidiness in the driveways or around the houses, shops pretty small and simple, a tropical feel to it'. And again: 'We had lunch of dosa in a glitzy mall-it could have been Brent Cross [in north London], except for the people and the open air that refreshed us. Suva is small enough not to be a city, but it is a capital with formal buildings like the Secretariat'.

Almost all my time on previous visits had been in rural settlements, and so, after a few days, I made for Korociri (which I had called Delanikoro in my book), in the Rewa valley not far from Nausori. Previously the settlement had been distanced from Nausori by open countryside. Now the road to the settlement was bounded by houses for its entire length, the temple at Vuci enlarged and decorated. In Korociri itself the pattern of settlement had changed, with a shift of population to the western part, and houses were half hidden behind lush gardens of trees and bushes. Only Damodar remained of the adults I had known in 1950 (see the 'whipper' in Peasants 1961: plate XIb). I was happy to see him not only because he had by now built and was managing an impressive temple, but also because 'I was delighted to hear him speak in Indo-Fijian Hindi"baitho" used for forms of "hona", and verbs used in the imperative'.

My wife and I had been especially close to two neighbouring families. One was headed by Pandit Brij Biharilal: his grandson Dharmendra was living at a much 
improved homestead though Dharmendra's mother Dayanti had died, much to my sorrow, for she was my wife's especial favourite and a marvellously spirited child and later woman. In Suva I later met Deven, the Pandit's great grandson from the other family branch and a highly successful businessman. The other homestead had contained Gangaya's large family, with whose wife, four sons, two daughters and a daughter-in-law (see Peasants 1961: plate XVb) we were in daily touch. The family was still there-his son Balram and granddaughter Savita, and her daughter Arti among others - and were warmly welcoming. With all these and others it was as if I had hardly been away: no Rip van Winkle feelings here! Although the homesteads and their surroundings looked very different, the welcome, the sense of humour, the food, in fact the general ambiance, hadn't changed.

The same could be said of my visit to Moto (Vunioki) on the other side of Viti Levu. Here again the countryside had changed, it felt greener and more 'overgrown'. (My perception of this change was not new, for I had noted it in 1971 (Peasants 1973: 195), but now I again compared it to 1950.) In Korociri we had stayed in a newly-constructed shop, a single room with an annexe behind: the shop was still there, but it had now grown to include a side room in which there was a billiard table, and I believe rooms behind.

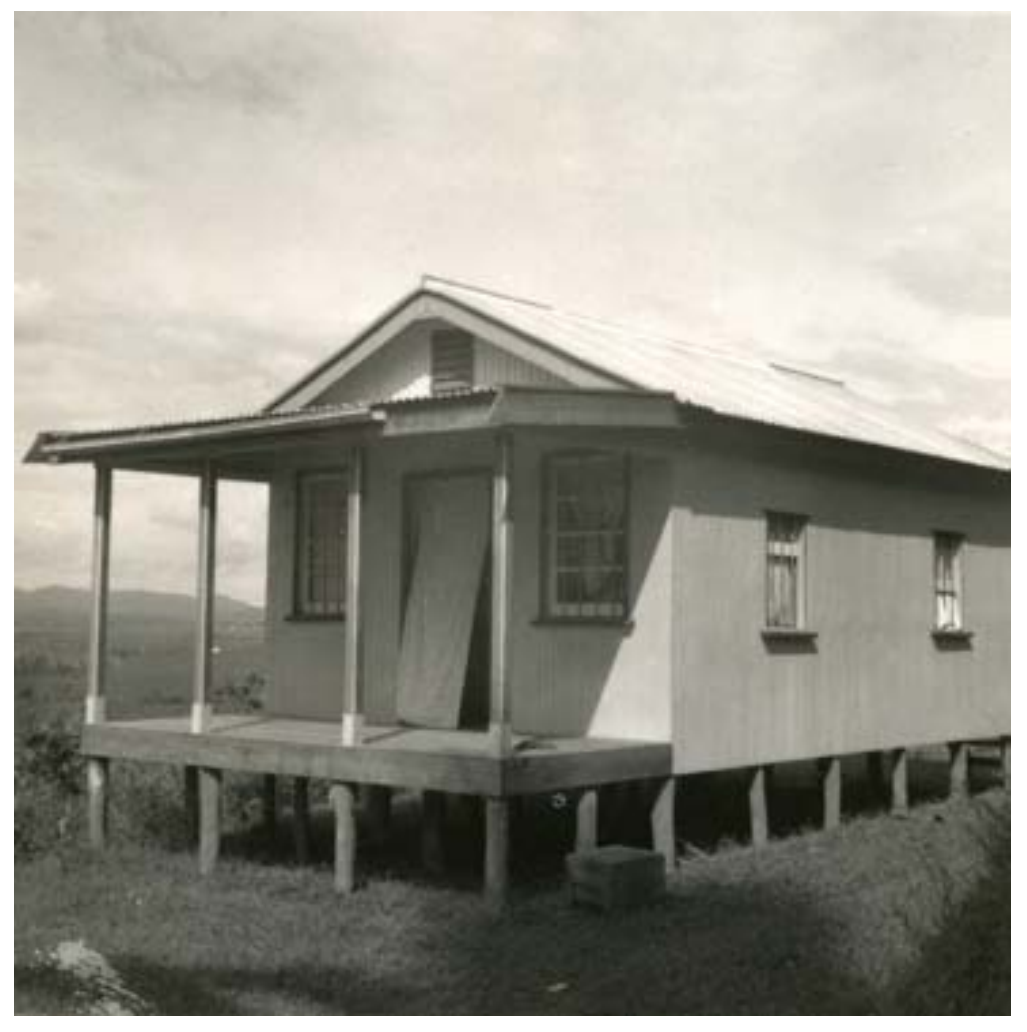

Figure 1: Korociri-Our house in 1950. 


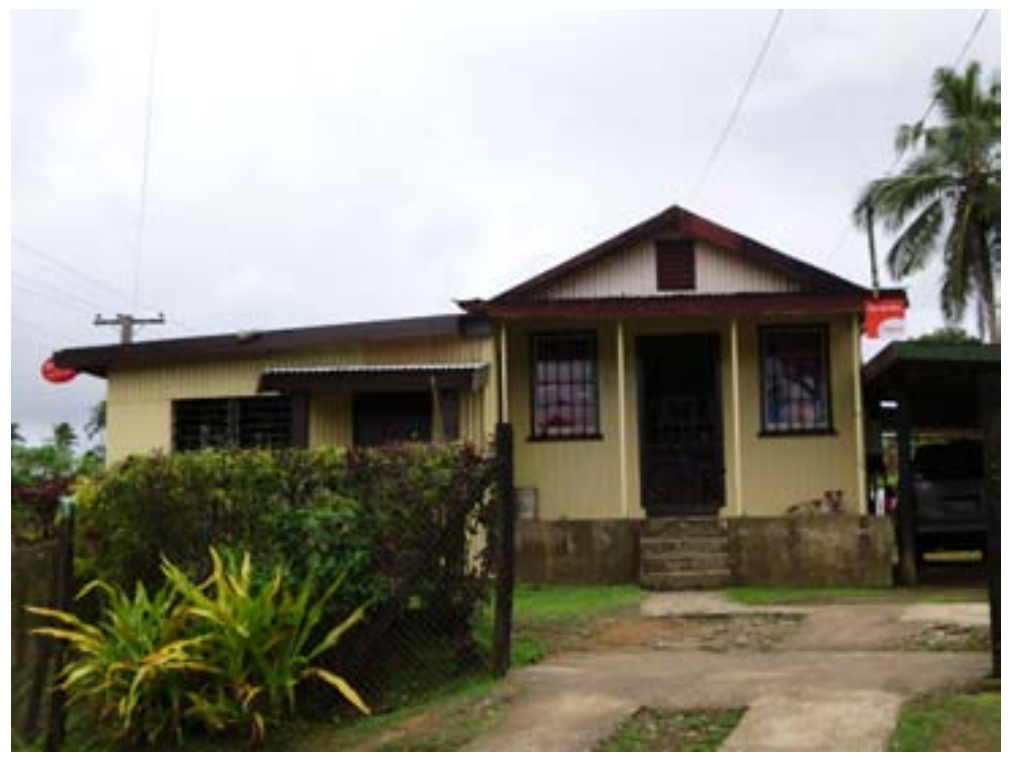

Figure 2: Korociri-Our house in 2010.

In Moto we had stayed in a grassy field which had two bures, one for our living and a smaller one for the kitchen. I knew exactly where it was, but when I got there I saw that the field had been partitioned and in it were three frame houses, one of which was on the spot of our bure, now shaded by coconut palms and surrounded by a garden.

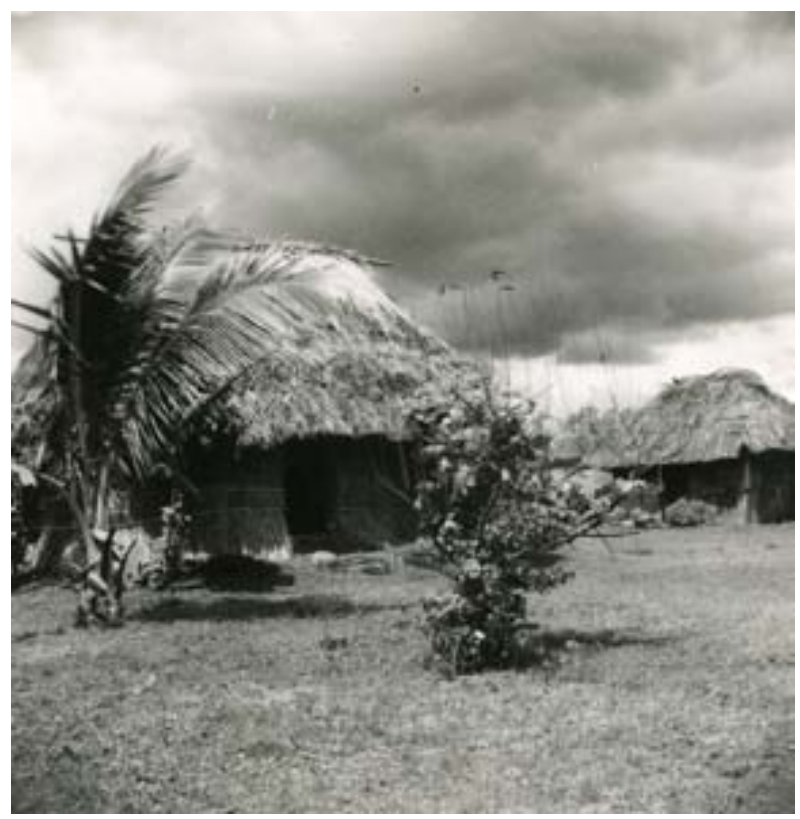

Figure 3: Moto-Our house in 1950. 


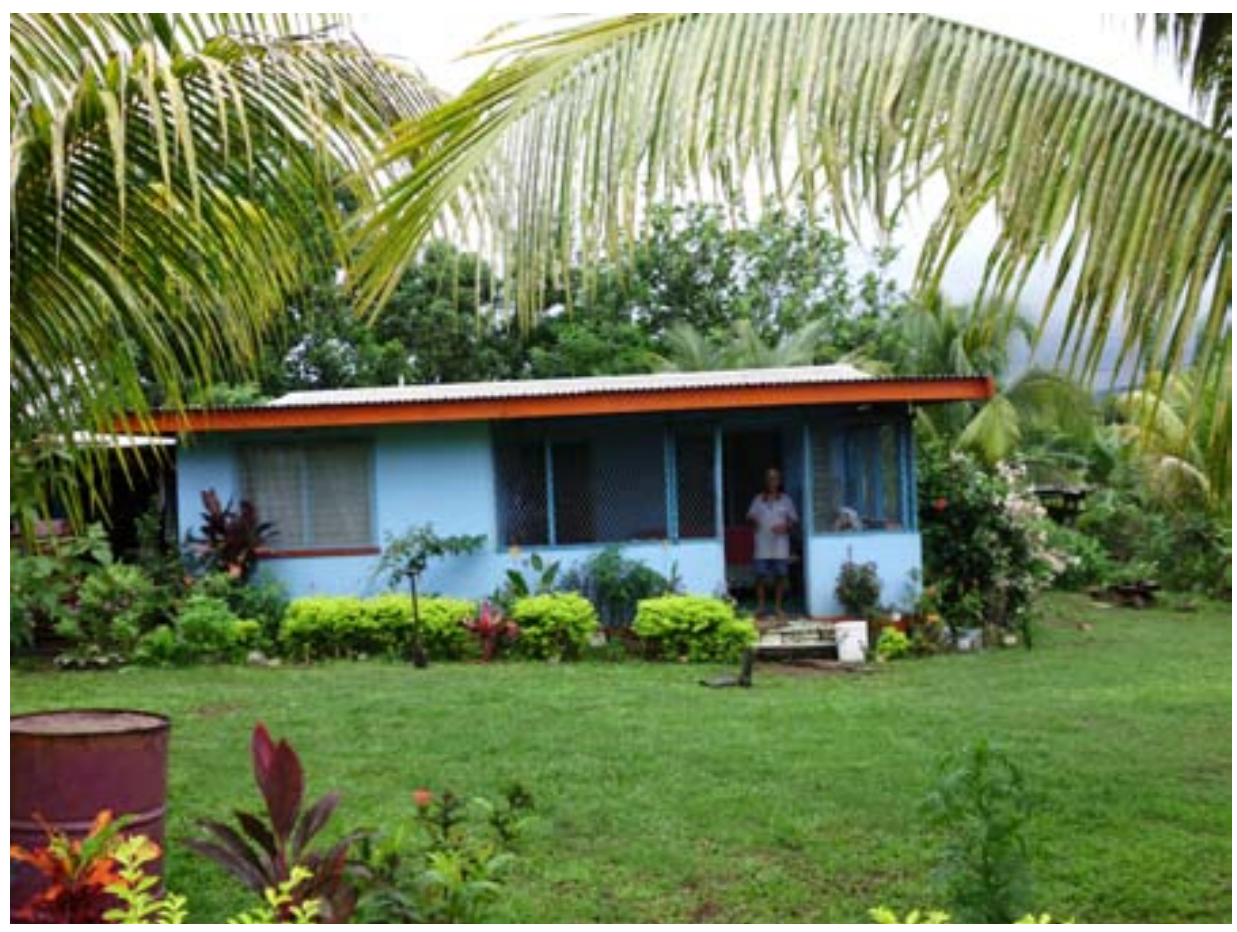

\section{Figure 4: Moto-Our house in 2010.}

I was downcast, thinking that all had changed, but when I enquired, I found that one of the houses was occupied by the brother of our then landlord Ram Das, a dainty little chap who had managed one of the two shops at the Moto cross roads. I had not known this brother, he was living in Tavua during our stay, but I quickly established our link and we had a most convivial evening together. As in Korociri there were people no longer alive, whom I missed-for instance, the three brothers whose faces look out from my book (Peasants 1973: plates XVIb \& XXa) and among them especially Parmanand Singh with whom I had stayed in 1971. Luckily Parmanand's daughter-in-law Rattan Kaursingh now occupied the homestead, and in two nearby homesteads were brother Arjun Singh's son and his widow. I recalled Arjun's house as I had seen it in 1971 and compared it with Rattan's present bungalow. 


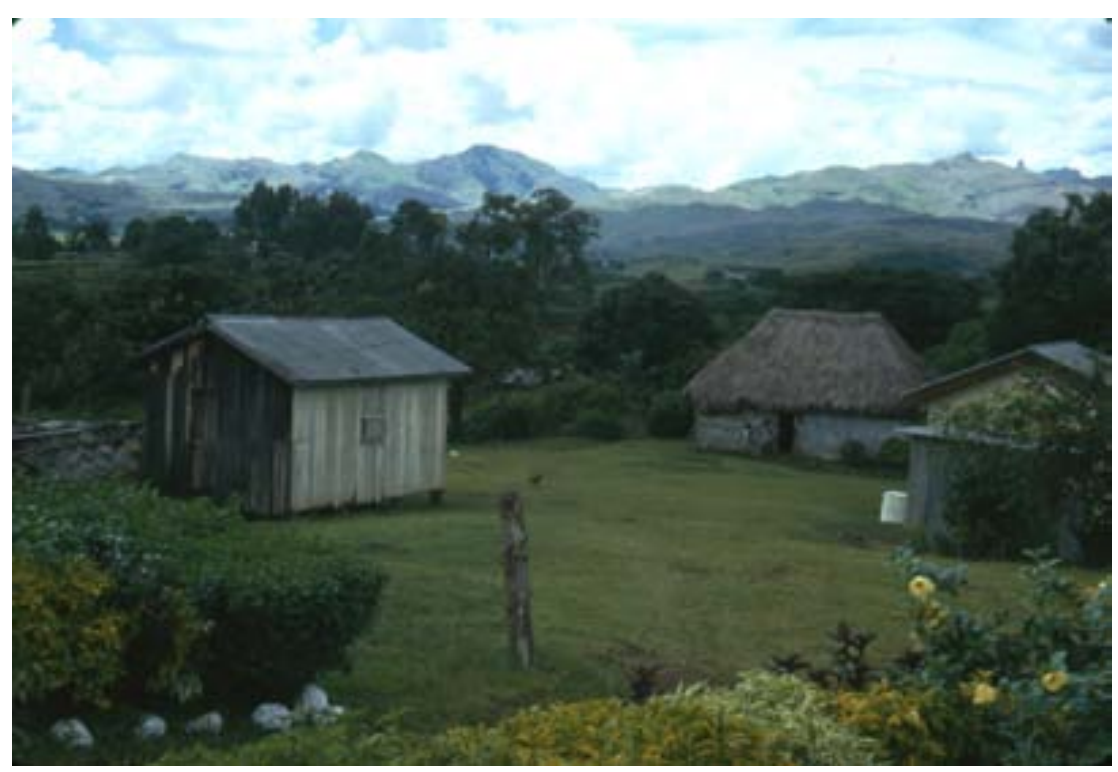

Figure 5: Moto-Arjun's house in 1971.

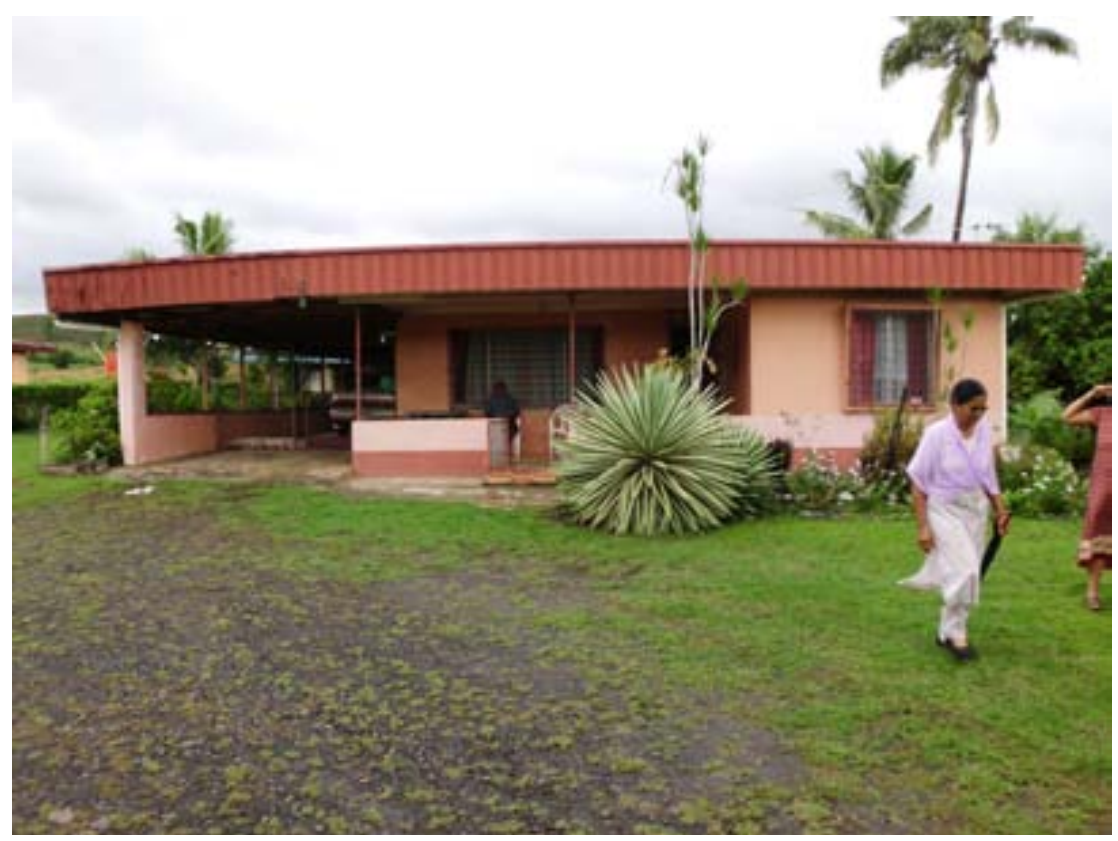

Figure 6: Moto-Rattan's house in 2010.

The third settlement, Coqeloa (Naboulima), on Vanua Levu was the place in which we had spent the least time; nevertheless I was keen to see it again. My first surprise came when I arrived at what had, in 1950, been the end of the 
road-literally, for only the CSR railway went on to the Wainikoro valley. In 1971 there had been a rustic signpost, but now there was a smart roundabout with a sign saying 'Welcome to Coqeloa' and the road continued past it.

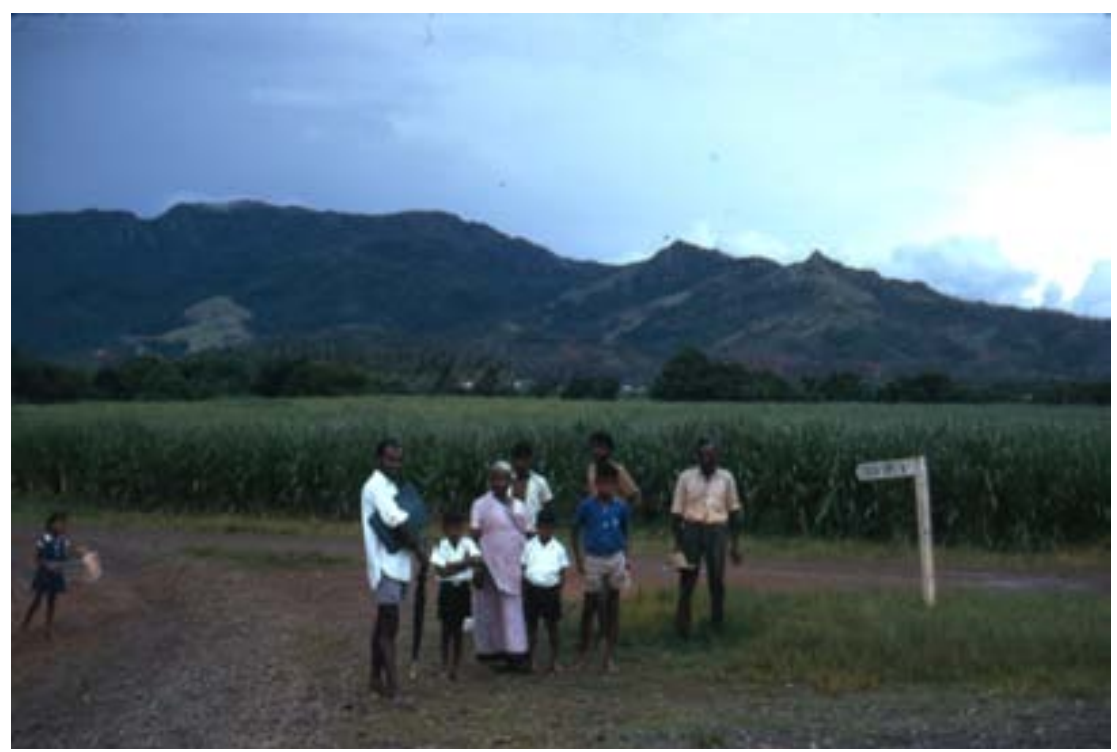

Figure 7: Coqeloa-Road junction 1971.

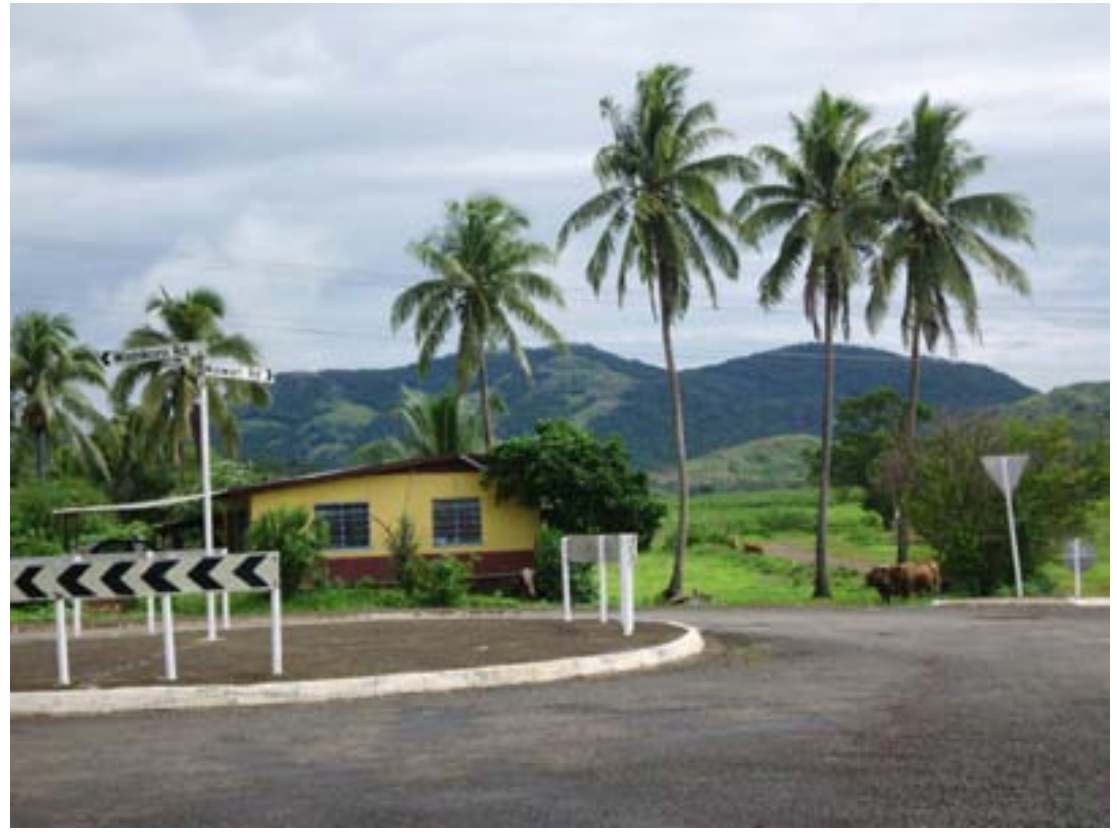

Figure 8: Coqeloa-Road junction 2010. 
Nearby was a shop, and from it I learned that my friend Girwar Prasad was no more. I went to the homestead where we had been Shyam Lal's guests as the occupiers of his storage belo; alas, neither he nor Ram Lal his son were alive, though their descendants welcomed me. The homestead had been so rearranged as to be unrecognisable, but the contours of the settlement were as I remembered them. Coqeloa is situated in the valley of the Bucaisau river where it emerges from the hills into a wide plain, with rocky mountains on the inland side, giving some of the most beautiful views I have seen in Fiji (see Peasants 1961: plate Ib). Searching for the temple to Ganga Mata I came to the site of the CSR overseer's house, where Mr and Mrs Wilkins had been hospitable to me when I came down with a bout of appendicitis. In its place was a school: it looked impressive, but I was told that its numbers had been diminished by emigration and a low birth rate from a former enrolment of some 300 children to its present 130 .

Nearby Labasa had changed of course, but it was still a fairly small town (though in 1950 we thought it a sophisticated centre for recreation!). We had stayed at the Grand Eastern Hotel, which had been a 'Somerset Maughamish' place in the '50s but which had now been enlarged and modernised.

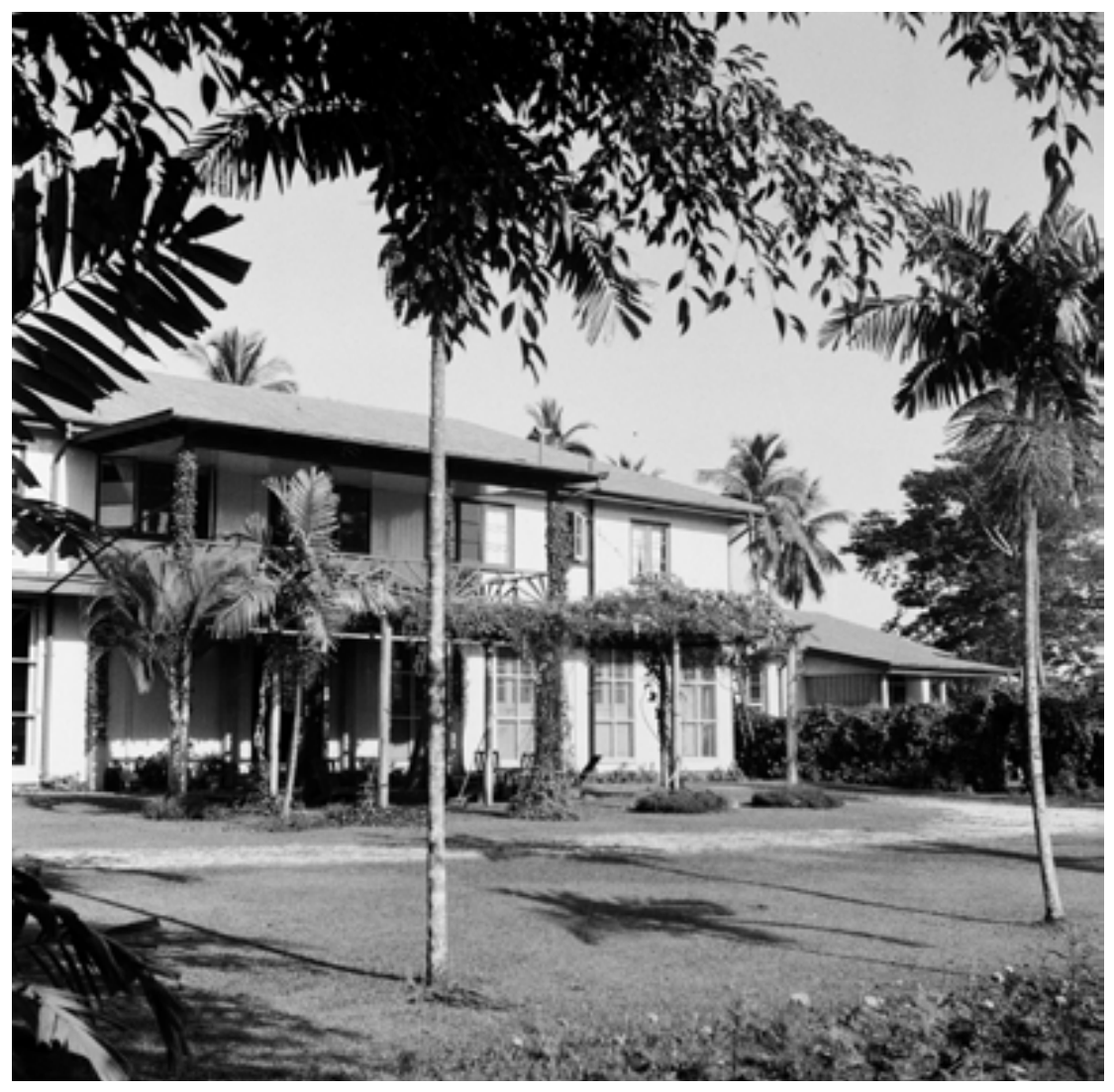




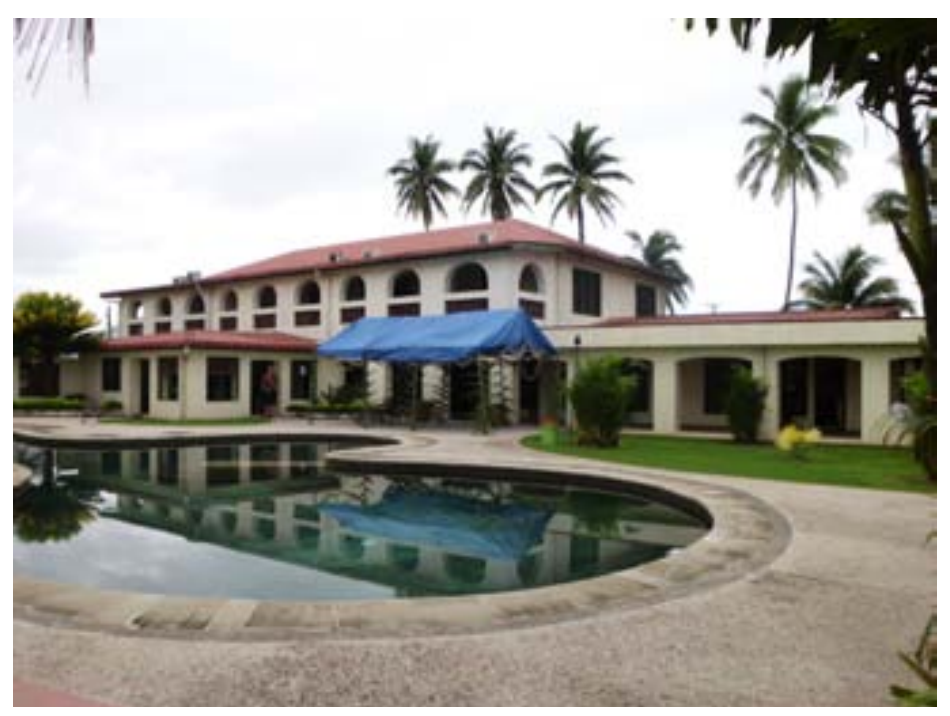

Figure 10: Labasa-Grand Eastern hotel 2010.

Nobody from the days of H.B. Gibson the proprietor and his friends was around, but I had a very enjoyable meeting with Paul Jaduram, whose father had given us a memorable send-off feast, and at whose Majestic Cinema we had been avid clients.

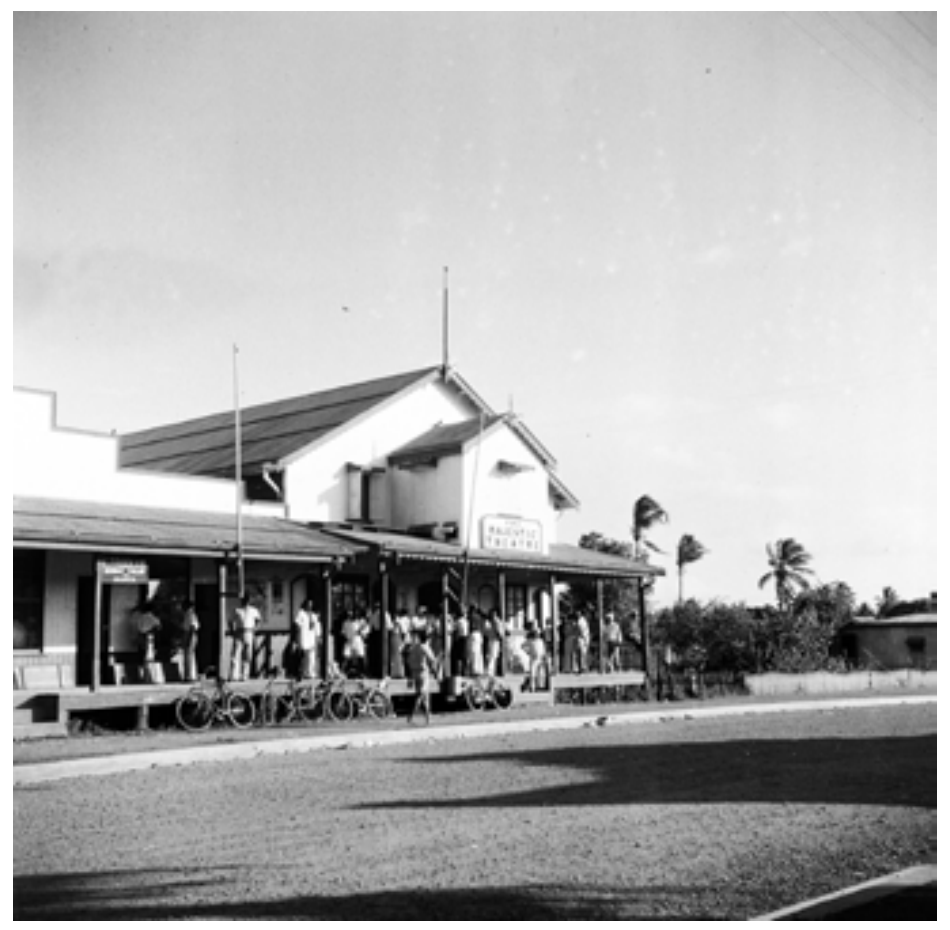

Figure 11: Labasa-Majestic Cinema 1950. 
Paul's daughter told us that there were now no fewer than five hotels in Labasa, partly due to the flow of pilgrims from other parts of Fiji (as well as overseas) to the Nag shrine on the outskirts of town. The rock representing the deity is said to grow miraculously, and the reader can judge from the photos I took in 1950 and 2010 how true this is.

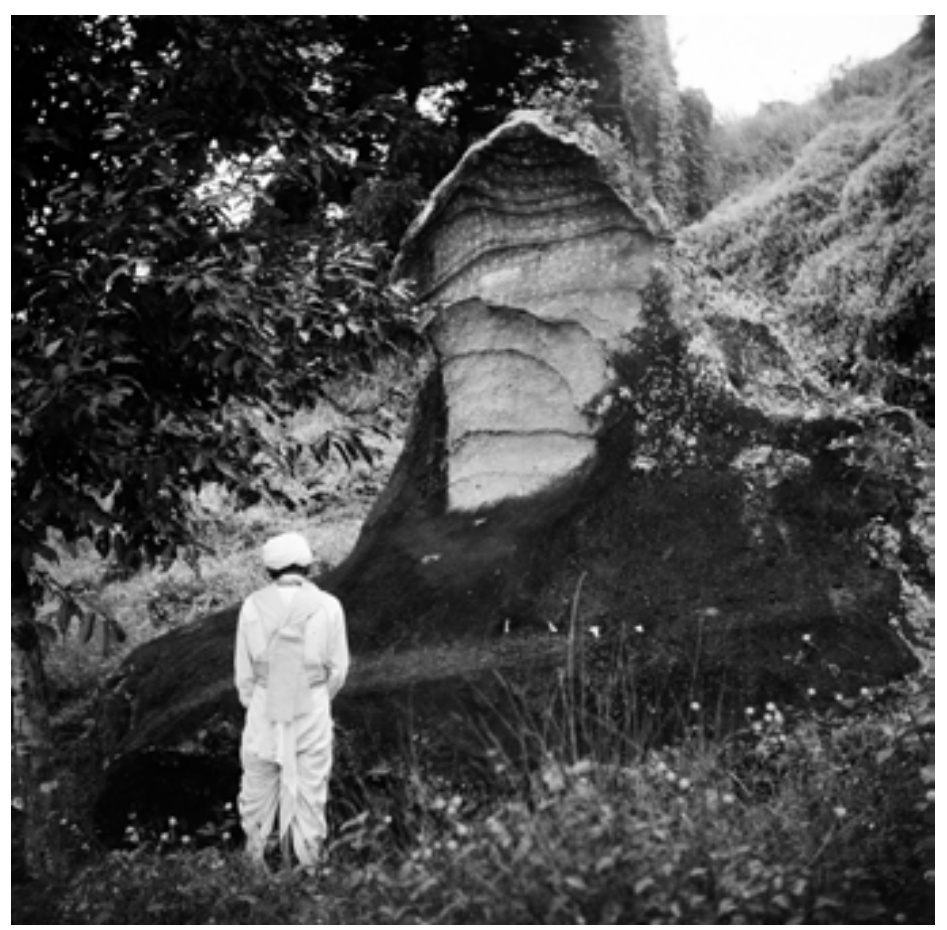

Figure 12: Labasa-Nag shrine 1950.

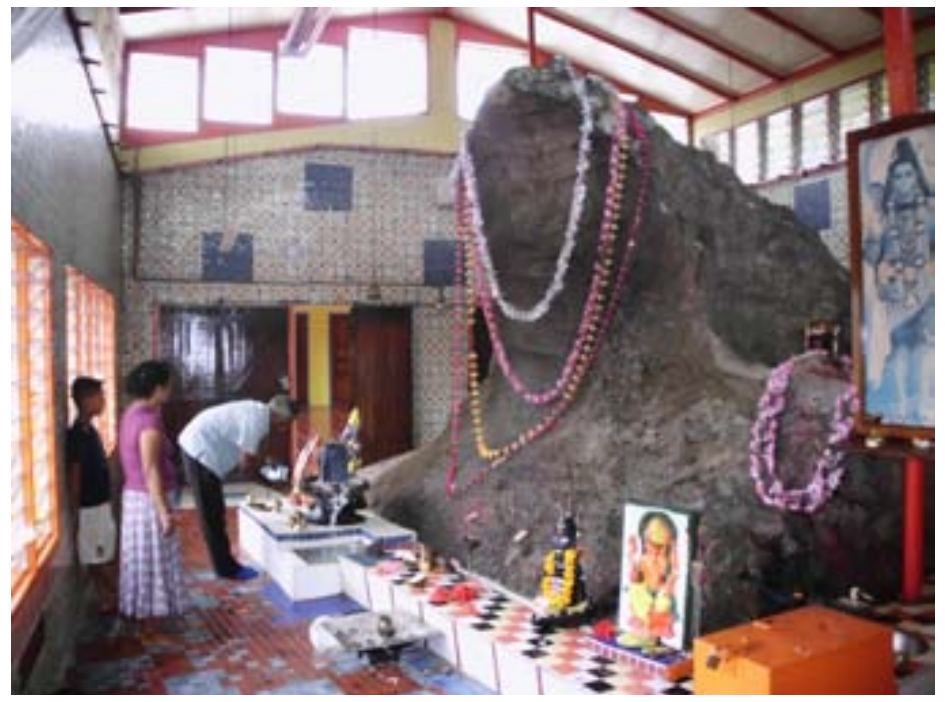


It was in Moto that I felt most like Rip van Winkle, perhaps because I knew that settlement best. As I gazed over the green and wooded countryside that lay under the line of hills to the south I identified the location of homesteads, giving them the names of the proprietors I had known. These were the names from 1950 not 1971, for the former were the clearer in my memory. 'Isn't that X's place?' I would say, and the reply, after a somewhat stunned silence, would be 'Yes, but it is actually now Y's place, though I do remember X's name', perhaps that of an indentured grandfather long since gone. From this we might start talking about 1950, or 1971, recalling events which marked the settlement's history - for instance about weddings or disputes, the knowledge of which made me a genuine, because I think trusted though transitory, participant in the settlement's history.

Many material aspects of life were very different in the three settlements. I have already noted the almost complete absence of bures in Fiji, but there were also few of the simple one- or two-roomed houses made of corrugated iron. In 1950 these had had little but basic furniture (beds, a table and simple chairs, usually a sewing machine, and tin trunks under the beds), with any decoration stretching to a few illustrated calendars and perhaps pictures of Hindu deities or the Ka'ba at Mecca. By 1971 frame houses had started to appear, but in 2010 these dominated, comfortable bungalows with a full range of household and kitchen appliances, and a sitting room with easy chairs and many ornaments fluffy toys, souvenirs, photographs - adorning the table on which stood the television. The standard of living had visibly and markedly improved, perhaps with the help of the occasional remittance from family overseas.

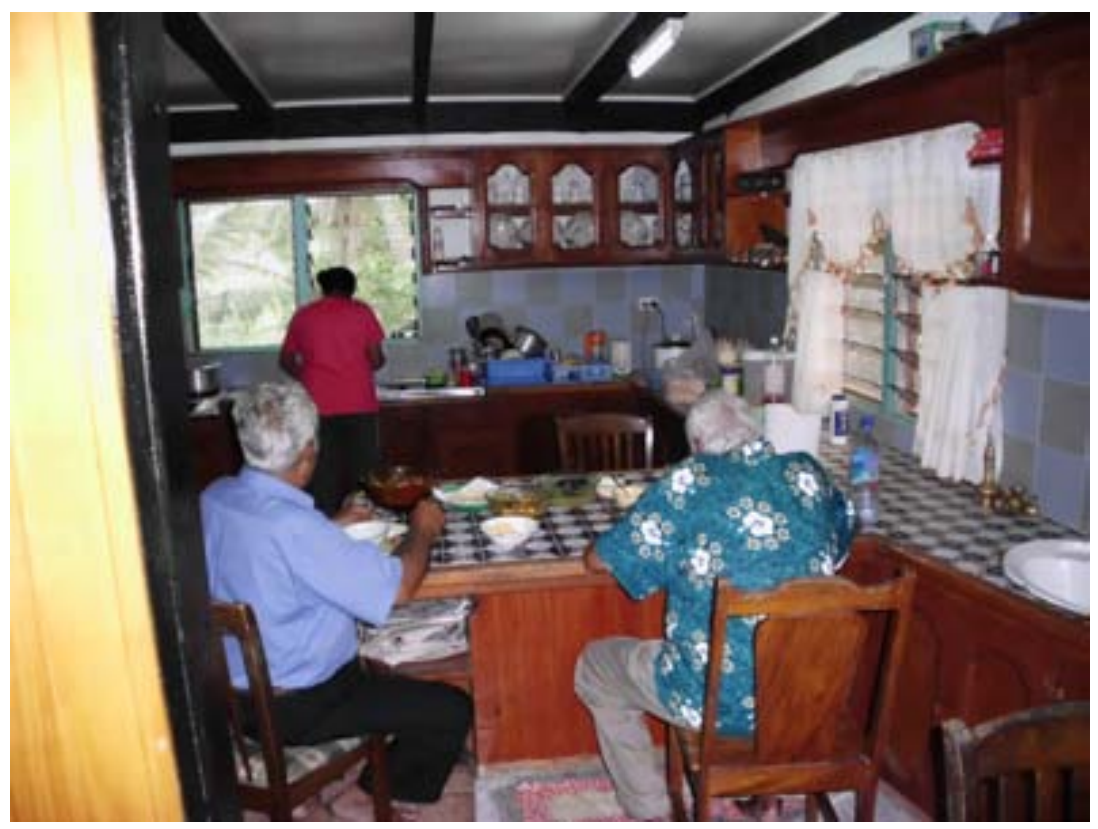

Figure 14: Korociri-kitchen. 


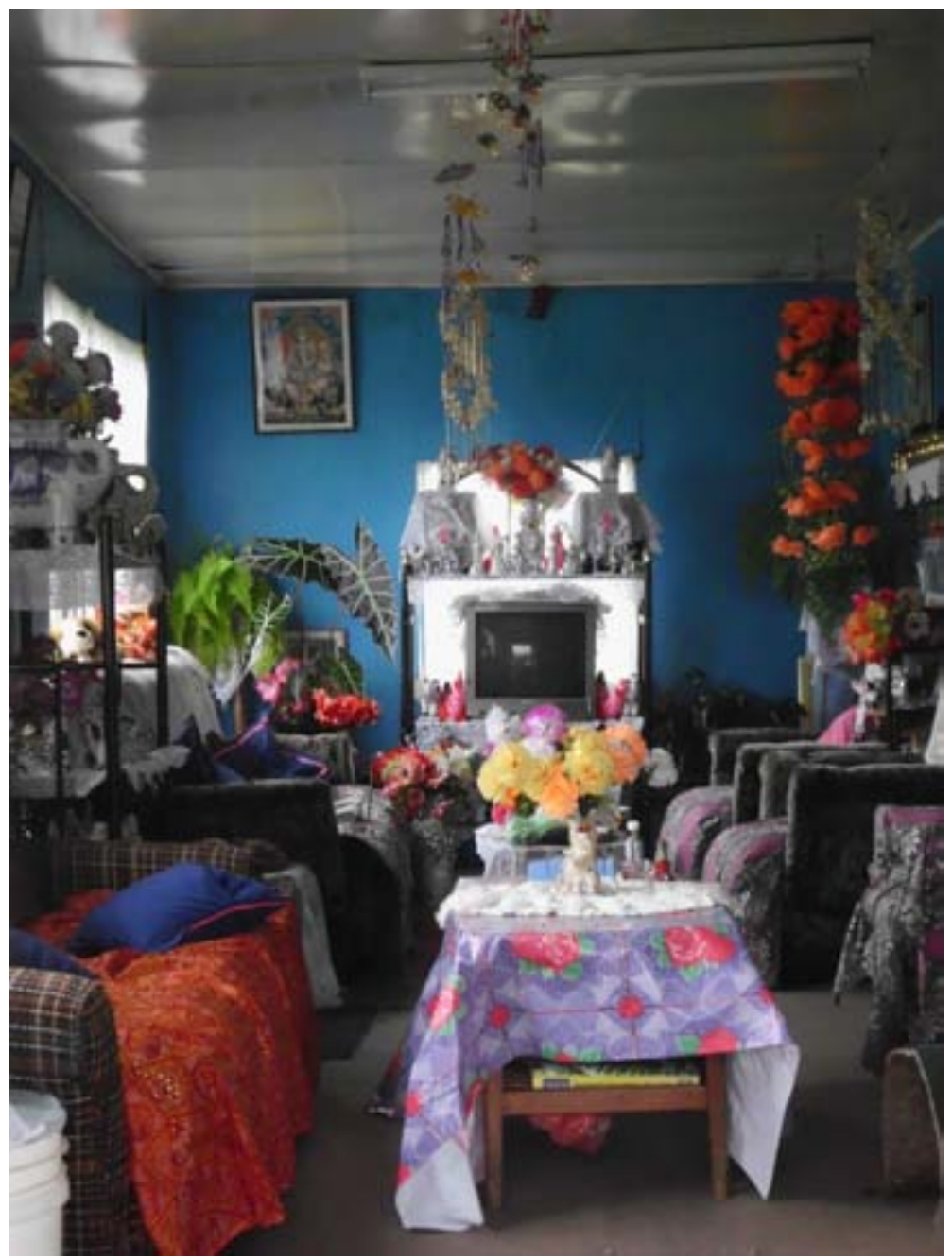

Figure 15: Korociri-sitting room.

The mention of overseas kin brings up another tremendous change. In 1950 kin groups had been relatively compact, since the founding, indentured, ancestor was in some cases still living, and in most others of only one ascending generation. By 2010 two or three generations had elapsed and families had spread, both into other settlements or towns in Fiji but especially overseas, principally to New Zealand, Australia, Canada and the US. However, it appeared that the mobile phone was keeping these far flung kin in as close contact as if they had been living at opposite ends of the settlement. When 'Sadhu' Chetty took me to Korociri I saw the house in which my good friend and Sadhu's father Rajaram had lived - and Sadhu straightaway called him up in Sydney and we arranged a day for me to meet him there. In Moto, I asked Rattan what had become of Parmanand's younger daughter Rajni, who had been the brightest 
of small girls in 1971, and whose photo I had with me. 'Oh, she is in Auckland' said Rattan, and at once telephoned her: as we spoke she recalled that I was the first person to give her a doll as a present. Later, her brother Anand in Sacramento called up to see how I was. I could go on. Almost all families had members overseas, sometimes all except the person who had stayed behind in Fiji to look after the property. A transnational family had been created, coming together for weddings etc. with visits both from and to Fiji, and staying in emotional contact through phone calls.

I found it interesting to compare this ease of contact with the outside with the situations in 1950 and 1971. In 1950 (Peasants 1961: 186, 188-90) I wrote that a few men went to New Zealand for temporary work only from Korociri, the nearest settlement to Suva. In addition, some of the remaining India-born availed themselves of the free visit to India allowed under their indenture contract. I described (189-90) the return of one of these men with other exindentureds (girmityas) ${ }^{2}$ on the steamship Sirsa, and how this excited little interest in the settlement, by contrast to the welcome given to a few young men returning from short working visits to New Zealand. In 1950, interest in India came mainly through Indian films and to a lesser extent radio and newspapers.

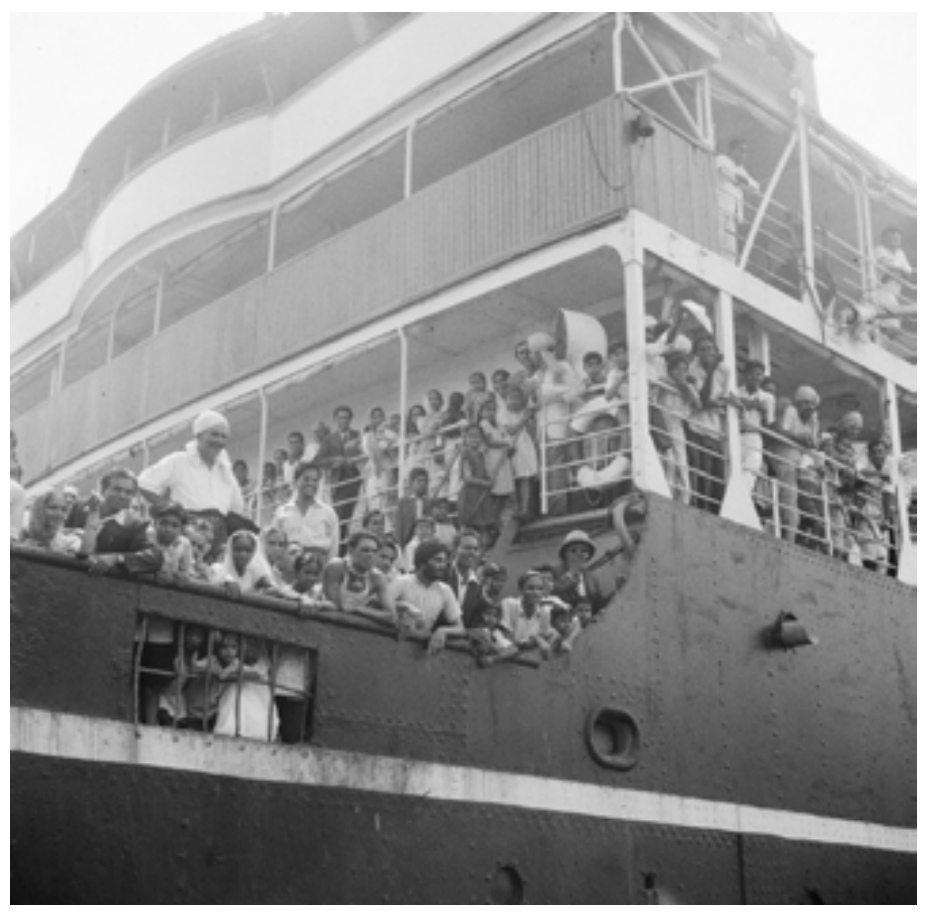

Figure 16: Suva-Arrival of the 'Sirsa'.

2 Girmityas/girmitiyas: indentured labourers. Girmit, the term for the indenture system, is thought to derive from the English word 'agreement'. $E d$. 
By 1971 the situation had changed. Not only were there many more men who had gone from Korociri to temporary jobs in New Zealand and the New Hebrides, but the nature of journeys to India had altered. By now there were very few if any girmityas left, but the following generations had the education, money and curiosity for a few to seek out their ancestral villages. I met some who had done so, as my diary notes. One 'had learnt before going, the names of people in Fyzabad from letters his mother used to receive'. He wrote to them and was received and lodged 'in a modern house "with crockery, tables and an o.k. lavatory"'. Later he went to the village, but didn't stay there and fell ill from 'heatache' [sic]. I note for another visitor: 'when he left from the station his three relatives stood rigidly with hands in namaste till the train was out of sight, [and] he felt a great lump in his throat'.

By 2010 visits to and from overseas relatives had become banal, and I now noted an interest in ancestral genealogies. When I spoke with people about the ascendants who had lived in their present homesteads at the time of my first visit, they wanted to know how I recalled these links. I showed them their genealogies, and sometimes they would spread these out and have amusing and sometimes controversial discussions bringing them up to date. I well remember such an occasion in Moto, where the genealogy of my old friend Mustafa's son Mobin was spread out, the talk being accompanied by generous bowls of yaqona before an excellent dinner

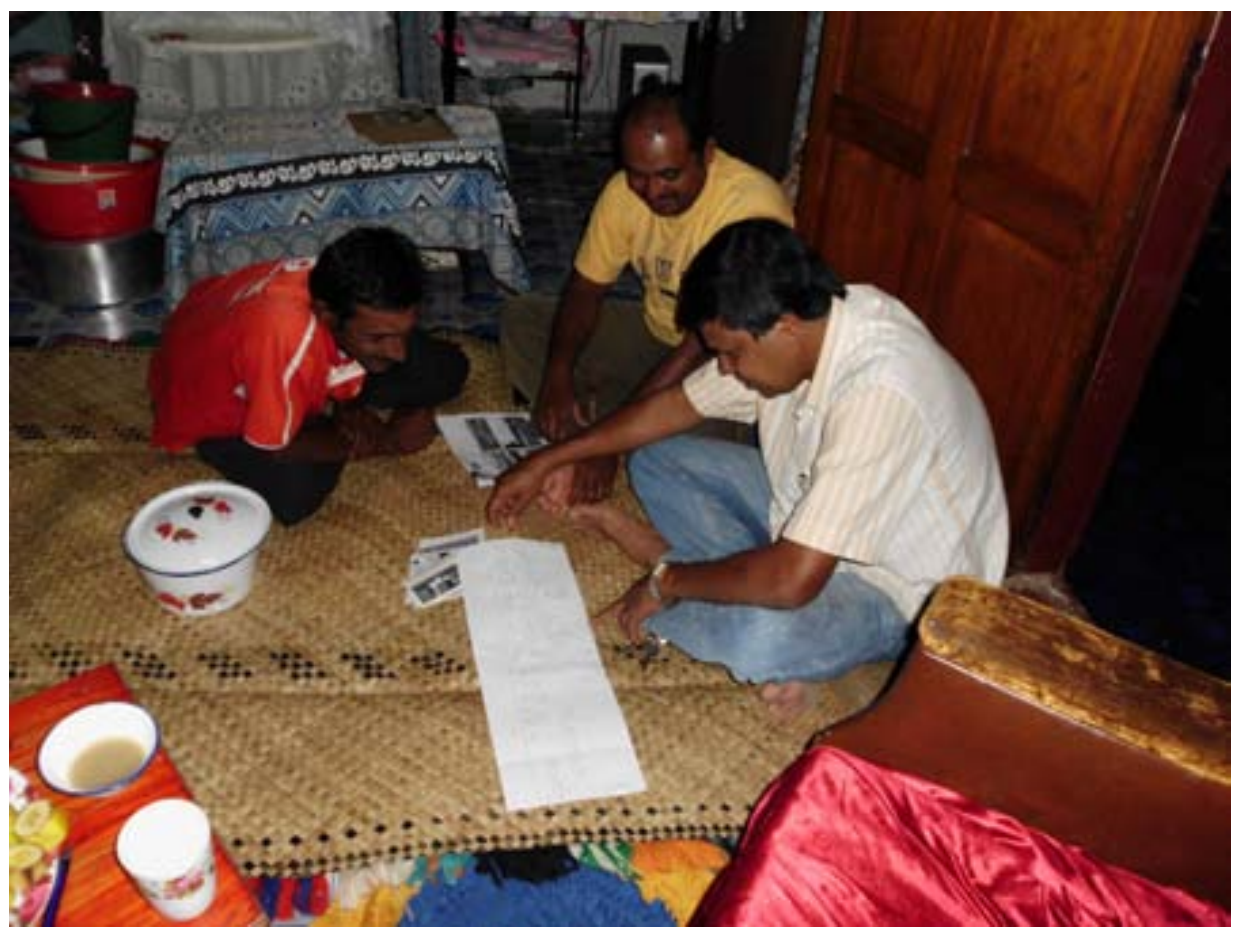

Figure 17: Moto-Scanning a genealogy. 
In this way I also got an idea of the very extensive outward migration of so many of these families. In 1950 the India generation had still been present, represented by perhaps cantankerous or boring old men, and interest in their stories was small. By 2010, these men had vanished into a second or third ascending generation. The interest in the genealogies of that time, sometimes including shipmate (jahaji bhai) ${ }^{3}$ relations, evinced a similar desire to 'return to roots' that the visits to India had shown in 1971.

Besides the genealogies, the photographs I brought served as my introduction. These were mainly the portraits of individuals taken in 1950. I had some 60 of these, and was able to distribute almost all, some directly to relatives and others to people who undertook to pass them on to a relative perhaps now living abroad. Some were delivered in dramatic circumstances, as this entry in my diary suggests: 'The sun was now shining as we drove to Moto to deliver a photo of Bangaru's wife to his son's son Chandra. We found his homestead more or less where I remembered it, and as we drove up to it we met a cane cutting gang, dragging cane loads by tractor to a lorry whose thickset, dark driver could only be of Bangaru's family. It was. I delivered the photo of his grandmother amid much oohing and aahing. It then turned out that another gang member was the son of Pabbar, so I could also deliver a photo of Nandan, Pabbar's girmitya father. Identifying various nearby homesteads, I mentioned Sukhari's. One of the cutters said 'That's my grandfather'. I replied 'I have a photo of Ram Devi with me' [see Peasants 1961: plate XIIIa). 'My mother!' So I was able to give him the only photo he had ever seen of his mother as a young woman. As I wrote: ‘He was absolutely overcome, flabbergasted - and so was I, moved by his reaction and also by memories of Ram Devi's friendship with my own departed wife. It was moist eyes and a big hug from this stocky, weatherbeaten cane-cutter'.

3 Jahaji bhai: in Hindi, literally 'boat brother'. Refers to the relationships formed between male indentured labourers on the long sea-journeys from India to Fiji and other destinations during the indenture period. These relationships often cut across caste, religious and other divisions that would have precluded such friendships in India. Ed. 


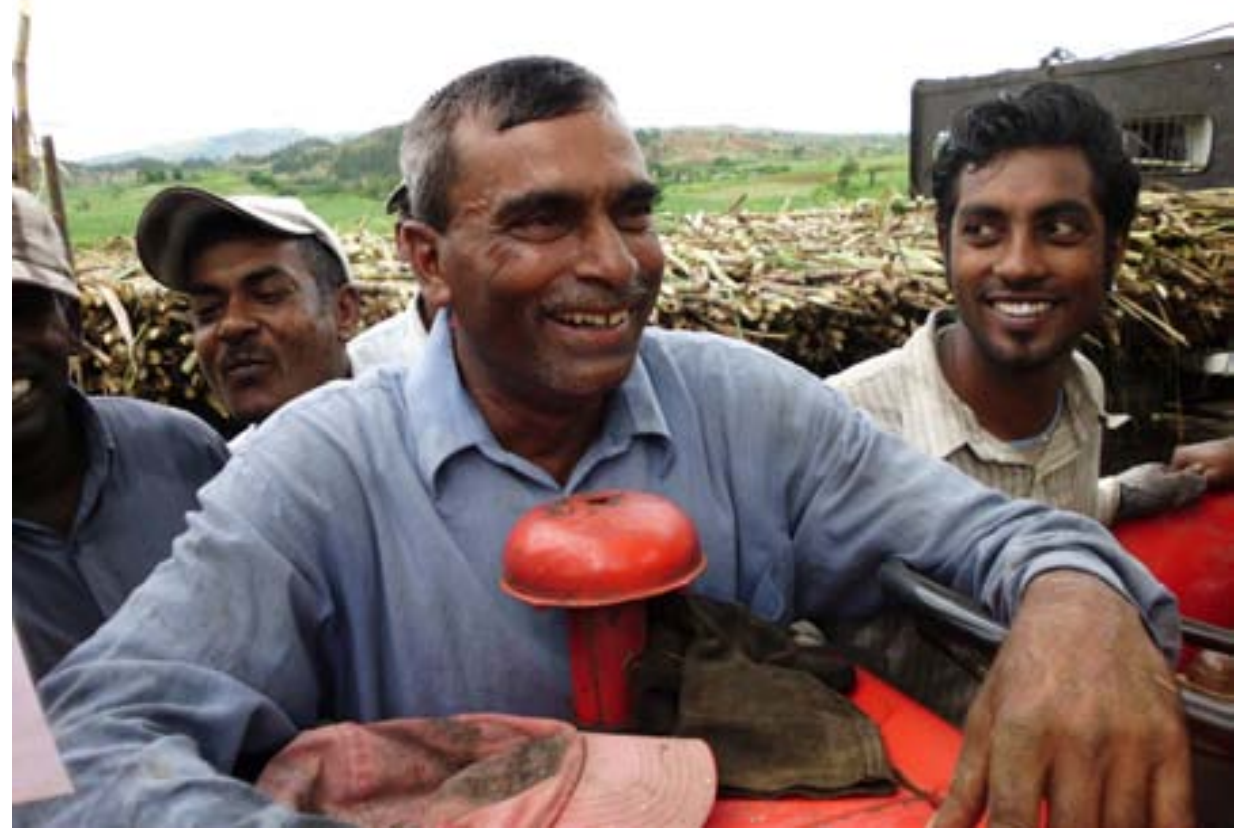

Figure 18: Moto-Ram Devi's son.

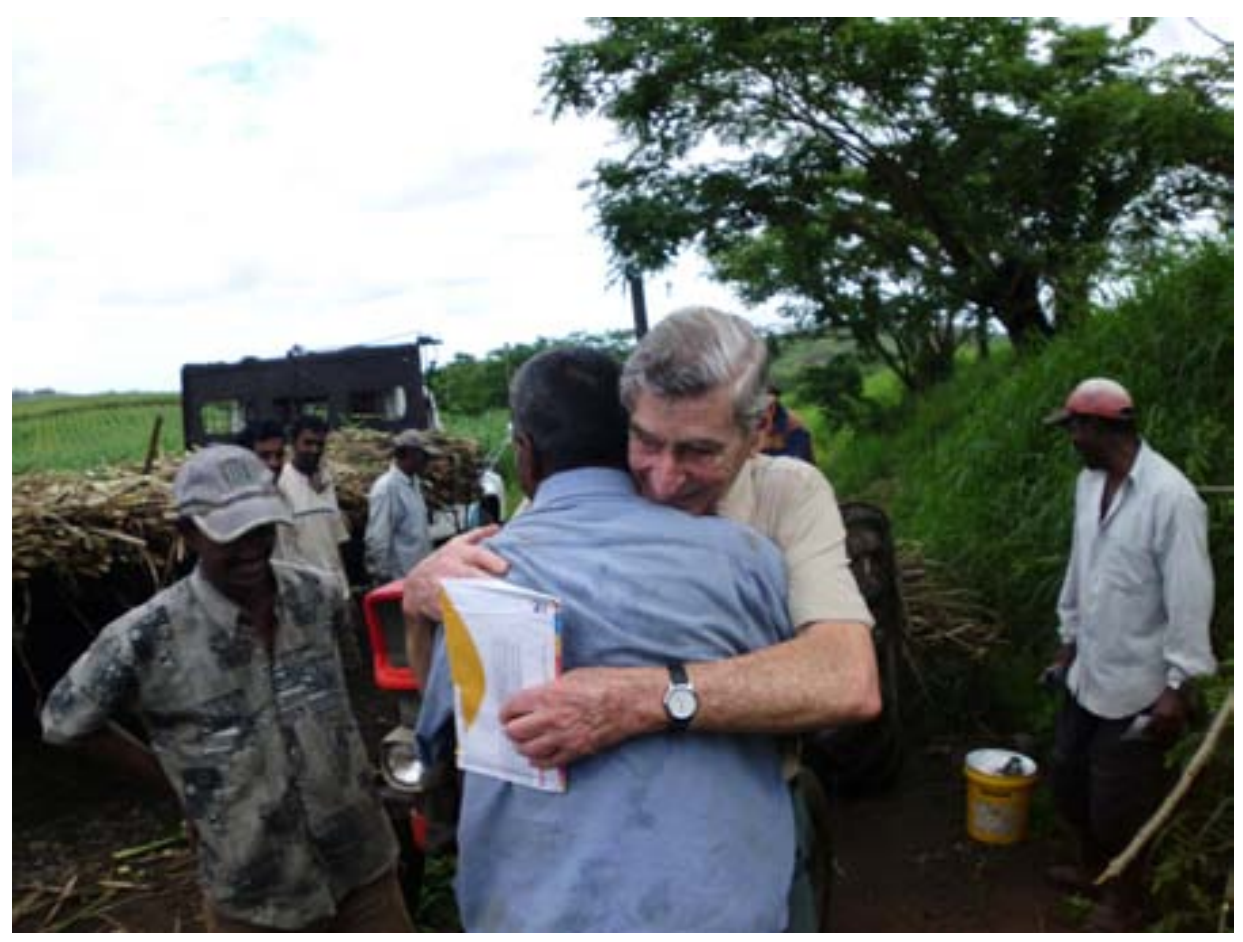


Again, in Coqeloa I was casually going through photos not yet distributed and came to a group of people whom I could not identify, when one of those present suddenly said 'That is my father', pointing to a small child held on the hip of one of the women, his grandmother.

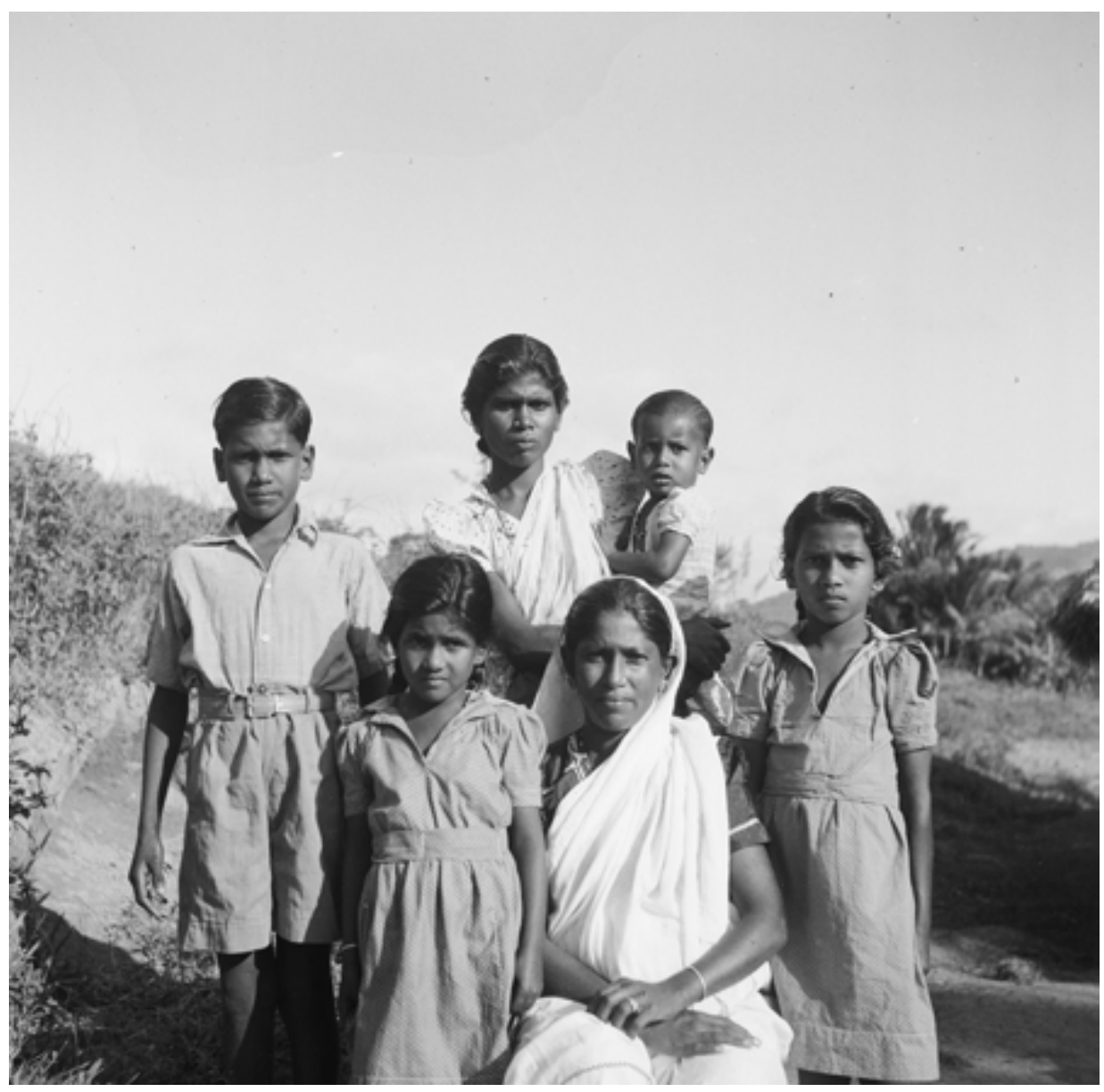

Figure 20: Coqeloa-Ashok's father as a baby in 1950.

He was thunderstruck and so was I, and I later delivered another copy to his father, now an old and sick man living near Nausori.

I did not in 1971 have photos to help in breaking the ice, though I was able to show my book to a few people. 


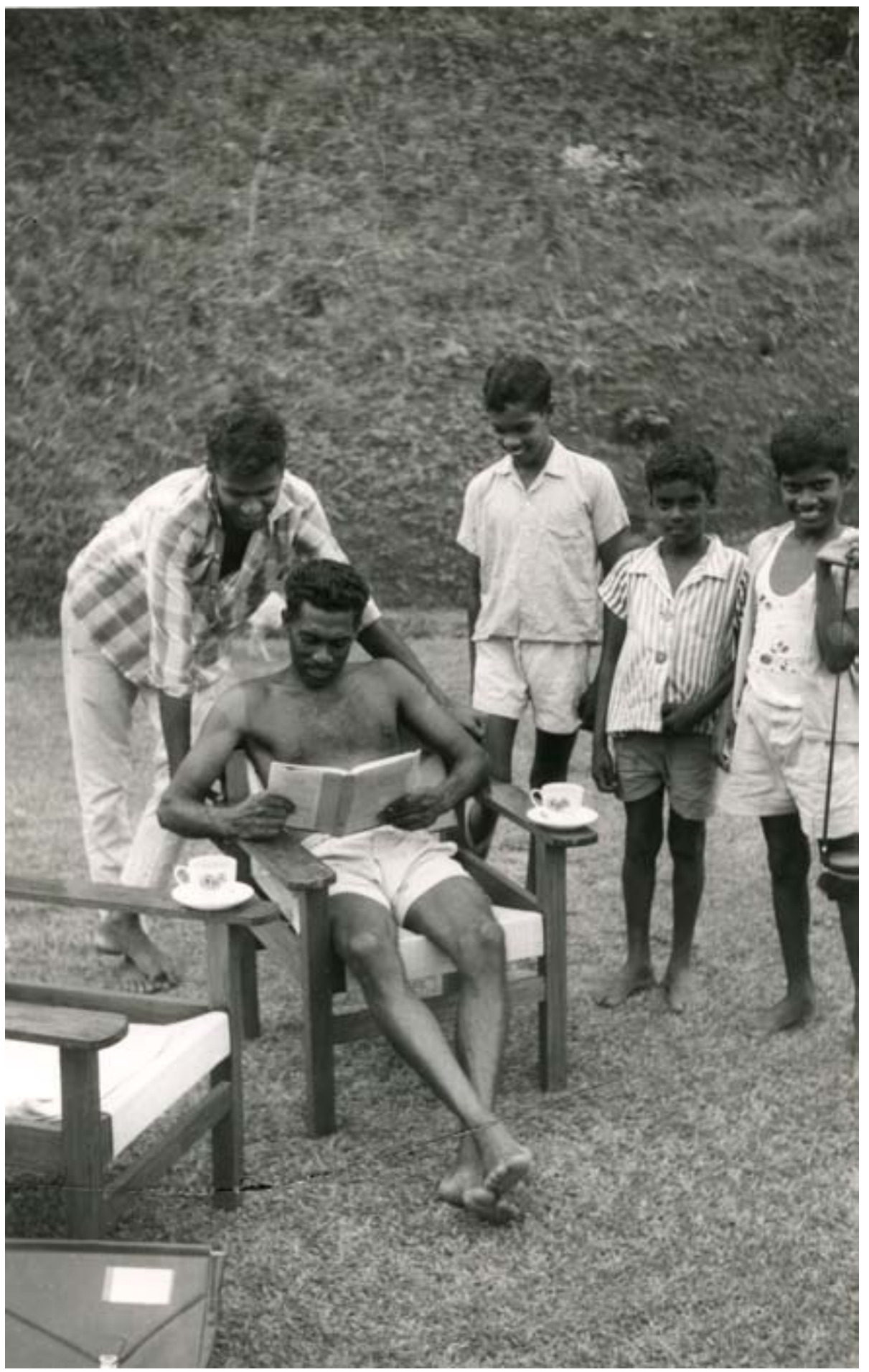

Figure 21: Korociri-Sanjibaiya peruses book 1971. 
Generally, however, the thaw took longer than in 2010, though with the same result. As I related in my diary of that time, 'I have been struck by the rapid change of attitude when people found out who I was. Coming to a house, people were completely hatchet-faced, leaning against the door, watching me approach. My first questions were answered with a minimum of expression and words. [But] then, when light finally dawned, an immediate change took place. A chair, tea, food was offered, animated talk, the lot'.

Travelling to the settlements, I was impressed by the improvement of roads which had been fairly basic on earlier visits, and was also able to take new roads into the interiors of both islands which had been inaccessible in 1950 . Chris drove me by the direct road from Ba to Sigatoka, passing the marvellous scenery around Mbukuya, and we also went along the Waidina valley with its impressive gorge, continuing down the picturesque Wainikoroiluva valley.

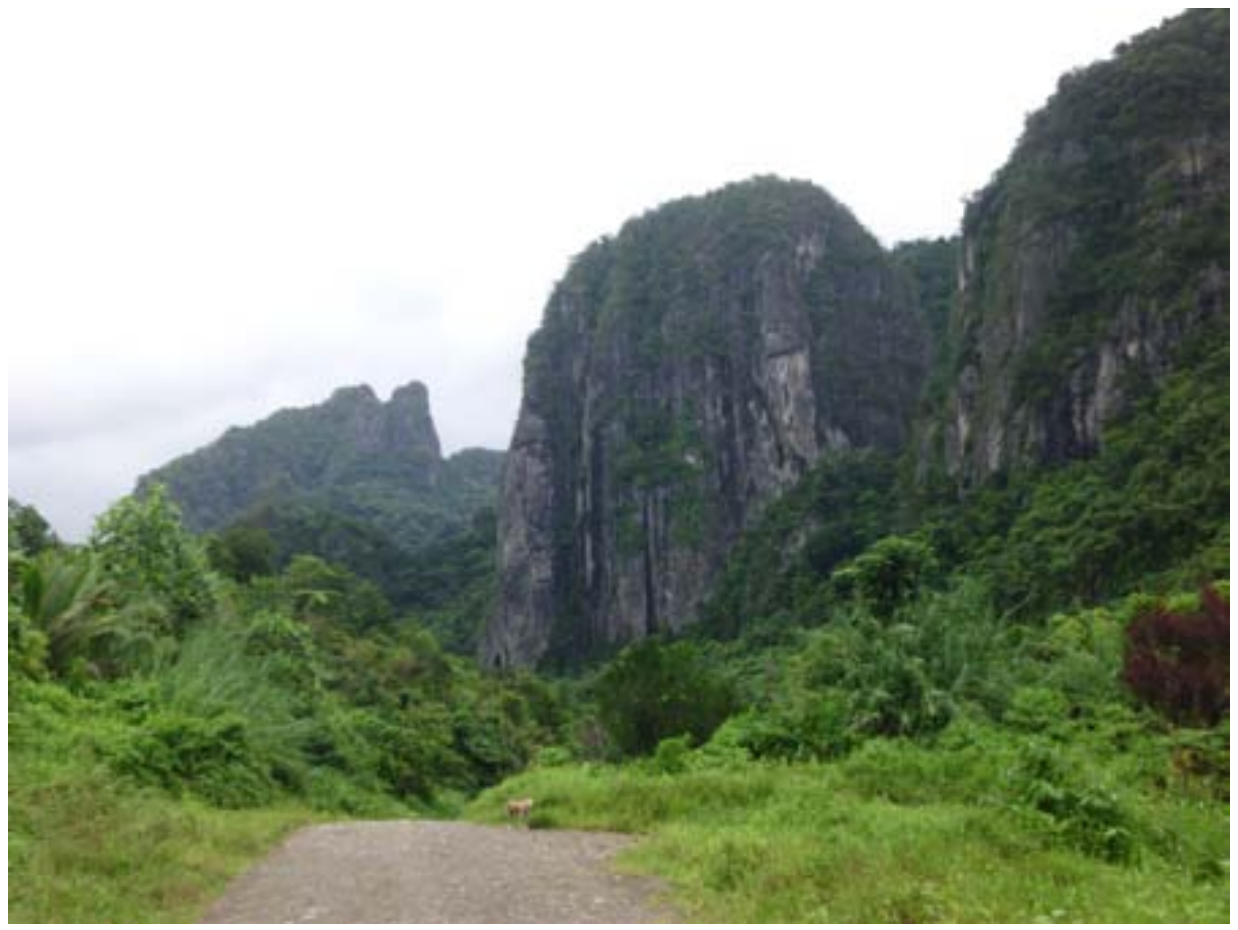

Figure 22: Waidina valley view 2010.

In Vanua Levu the road from Labasa to Savusavu was exemplary, and the rough road through the mountains from Vanuavou to the Bucaisau valley produced some splendid views but also evidence of the way in which the 'mile-a-minute' creeper has taken over large parts of the terrain.

4 'Mile-a-minute': a term used locally in Fiji to refer to several different introduced species of fast-growing creepers which now cover large areas of Viti Levu and Vanua Levu. One of these species, kudzu, was allegedly 


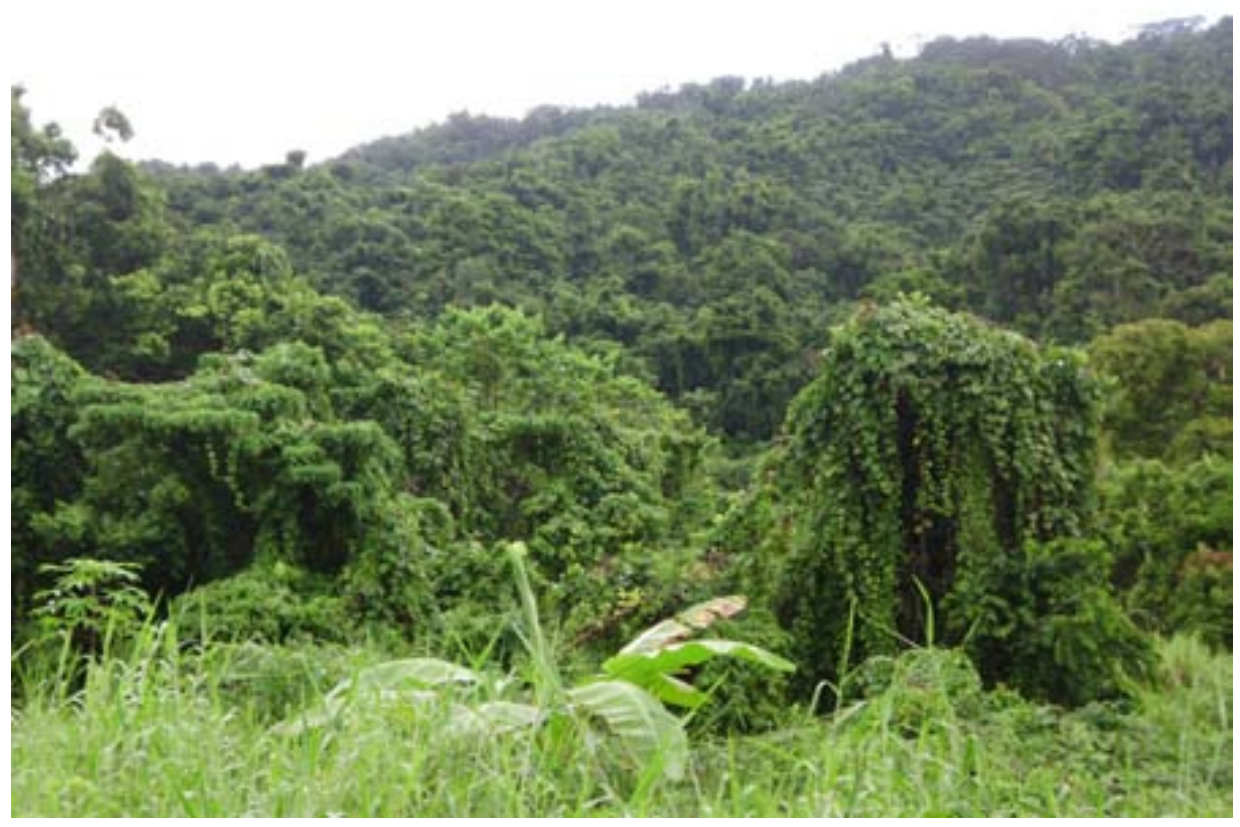

Figure 23: Vanua Levu-'Mile-a-minute’ creeper.

Can it ever be eradicated? This must be a mounting problem for any future development of these areas. It was good to be able to see for the first time the beauty of the interior as well as Navala village, built entirely of bures and looking like any of those I had seen in 1950 but now a tourist attraction because of its singularity.

People frequently asked me: what changes did I see in the three settlements as a whole? On the basis of only a few days in each place I can only be impressionistic of course, but perhaps some random thoughts may be of interest. In 1950 one could broadly say that 'cane was king' in Moto. The cane grower walked tall when he came into town on a Saturday, and the elected head (sardar) of the single cane-cutting gang was a powerful and respected figure, his position much sought after. Behind the sardar lay the power of the Colonial Sugar Refining Company (CSR) to which the growers were contracted and which had an overarching position in regard to cultivation, collection through its rail system, and milling.

introduced to Fiji by American armed forces during World War II, to serve as camouflage against Japanese reconnaissance planes. $E d$. 


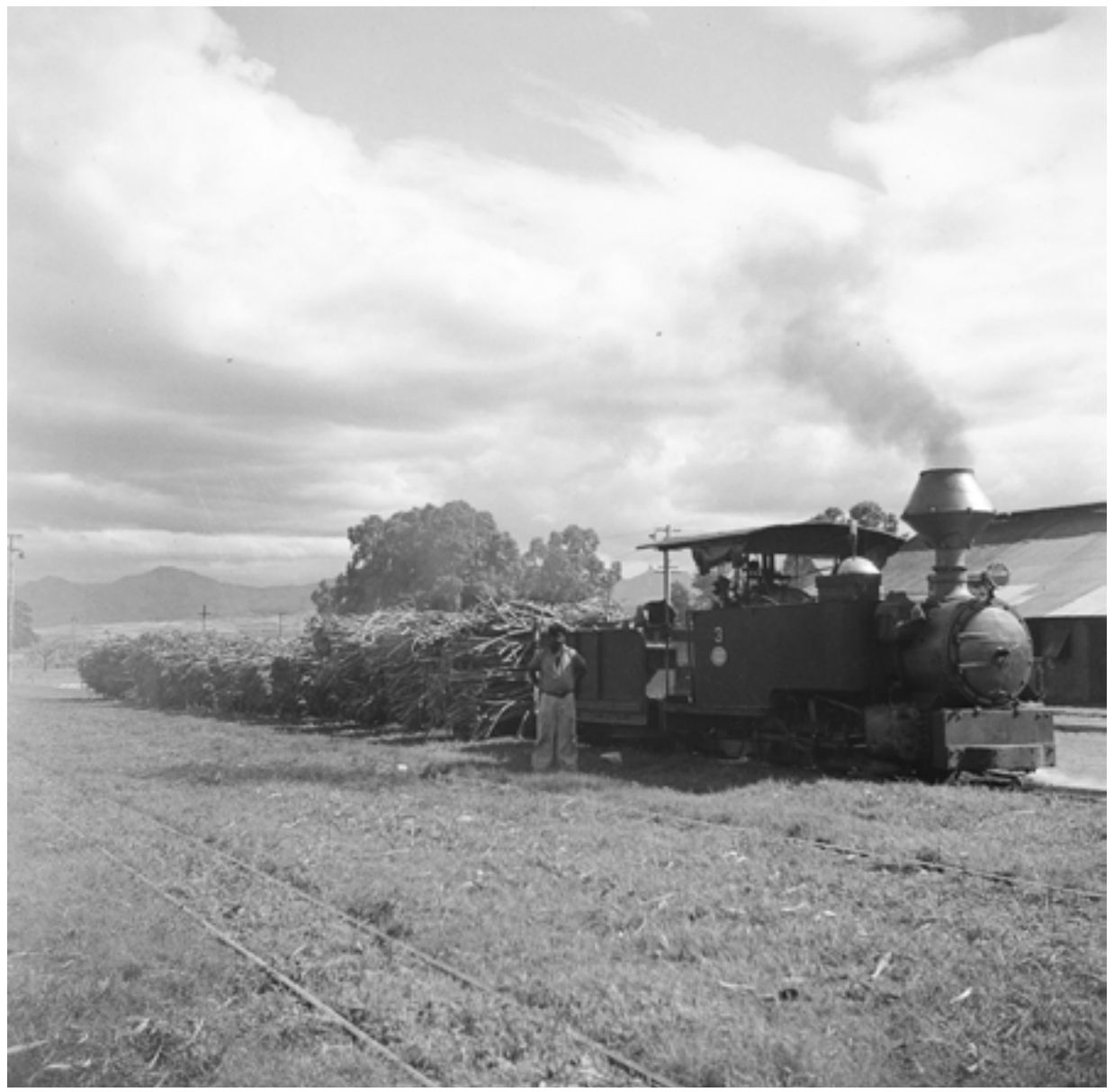

\section{Figure 24: CSR cane train 1950.}

Though some people practiced mixed farming, without cane such people were less important, and there were few occupations outside farming and few positions of authority beyond the gang, though skill in dispute settlement might add to a person's reputation.

By the time of my visit in 1971 the situation in Moto had been transformed. Cane was still king, but with a difference. It could now be cultivated on high ground that the CSR rail tracks could not reach, and the internal communication of paths had been transformed into roads which could be used by lorries to take away the cane (see Peasants 1973: plate XVIIb). As a result, there were many more growers - in fact almost all households were included, whereas in 1950 only $60 \%$ had been. But these were now in nine gangs, and authority was dispersed to their presidents and sardars, the latter now only executive officers. Of the men in non-agricultural occupations, one quarter were now commuting to Ba. My view was that the settlement had changed from being one in which 
farming was a way of life to one in which it was a way of earning a living, one of several emerging alternatives which included work in town to which several young people aspired. There were more people (an increase of $67 \%$ ), they were living better in terms of housing and possessions, but the settlement's articulation appeared to be less dense and more 'individualistic', with fewer acknowledged positions of leadership.

My impression in 2010 was that this trend had continued. Cane was still cultivated and now almost entirely transported by lorry.

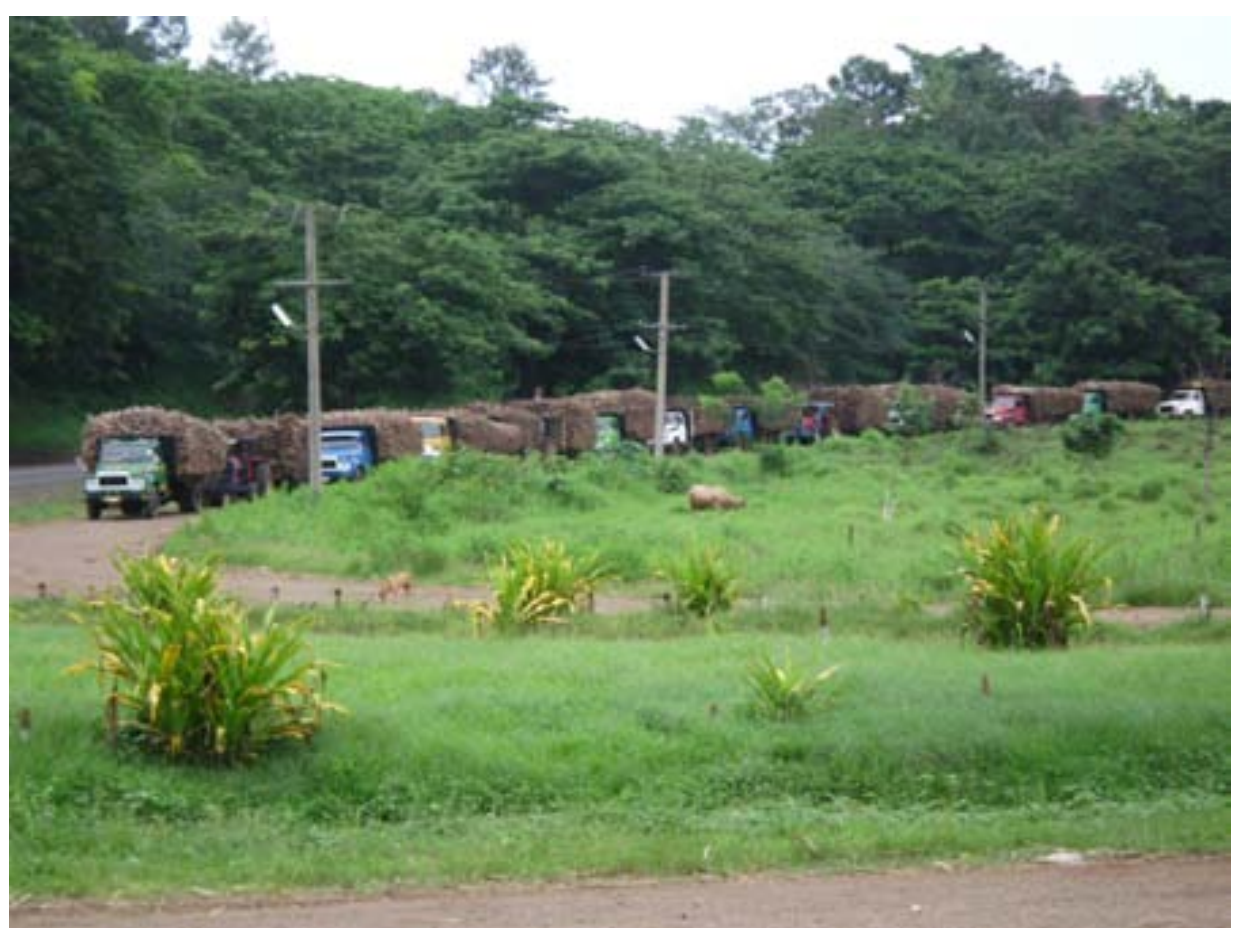

\section{Figure 25: Cane lorries at Labasa mill 2010.}

But its economic importance had diminished, for productivity was said to be lower and harvesting hampered by breakdowns at the sugar mill. Some farmers were turning to other crops - market gardening, pineapple cultivation. The gangs now included many Fijians, for want of local Indo-Fijian labourers. Moto supplied a member of the Advisory Committee, and in one locality there was said to be a Neighbourhood Watch to guard against petty larceny. But when I asked what would happen if there were a dispute or a fight, the answer was 'I would pick up my mobile and call the police'; earlier, I think it would have been to seek the help of an influential man in the settlement. The school, which had a management committee, was said to be 'only half full'. My speculation (Peasants 1973: 210) that the area around the two shops and petrol pump 
might develop into a social centre had not materialised - indeed the pump had disappeared and the shops were no larger than before. To all of this was added the effect of the overseas emigration I have mentioned. From the answers of those whom I met, some $40 \%$ of adult males of Moto households now lived overseas; and many others had turned their thoughts to possible emigration. In short, Moto appeared to be a 'hollowed out' community compared to the one I had known. I do not use the word in a pejorative sense. I mean only that a significant proportion of people's important social relationships, involving family and kinship especially but also economic, lay with those outside the settlement.

Korociri's difference from Moto stemmed from its geographical position, on the windward side of Viti Levu and only $5 \mathrm{kms}$ from Nausori and $26 \mathrm{kms}$ from Suva. Though in 1950 the settlement produced some cane, it was paddy cultivation that predominated and, though there might be informal groups cooperating on transplanting, for example, there was no institutional position of leadership like the sardar's. Already in 1950, 20 men worked full time in Nausori or Suva, with 12 others at the CSR mill. In place of the sardar the major leaders were those in informal associations - the Youth Association and the Ramayan Mandli- the former set up to organise cooperative settlement activities and arbitrate disputes.

By 1971 the sugar mill had closed and the population had increased by $23 \%$. This was less than half of Moto's increase, for several households had left Korociri, some to be near their work in Suva. In those remaining there were few full-time farmers, for the number of commuters had risen from $23 \%$ to $71 \%$ of adult males and Korociri had now become part of southeast Viti Levu's 'peri-urban zone' (Peasants 1973: 214). The Youth Association had morphed into a School Committee, but this was without wider aspirations of social control. Most young men had by now been to New Zealand or the New Hebrides (now Vanuatu) for fixed periods, though this source of work had diminished by 1971. Korociri in 2010 therefore presented a less changed appearance than Moto, because the settlement had simply enhanced its role as a dormitory suburb and its links with countries overseas had also continued, though changed from being ones of temporary labour on my first two visits to those of emigration.

I have a much less definite impression about Coqeloa. Suffice it to say that in 1950 it was even more than Moto a cane growing settlement, and that its distance from Labasa (to which it had only recently been connected by a bus service) meant that there were no commuters. I did not stay in Coqeloa in 1971, and my visit in 2010 was too short for much comment. Nevertheless, it was clear that cane cultivation had lessened in significance and that the settlement was now linked much more extensively to Labasa and the outside world (which here included Viti Levu to which a number of people had emigrated), though this seemed to be still less than in the other settlements. 
My thumbnail sketches show that the settlements have had somewhat different trajectories, governed partly by their geographical position and nearness to urban sources of employment, but that a degree of convergence can also be discerned. Factors behind this include: a) the decreasing importance of cane; b) the increase in commuters, this being correlated perhaps with a decrease in the density of internal social relations with the implication this has for local leadership; and finally, c) the growing importance of transnational kinship relations. Underlying these factors was a convergence of style and level of living. For instance, everyone now lived in a frame (or less often an iron) house, no longer some in a bure or belo. Again, all seemed to have similar furniture, including TVs. Some were of course better and some less well-off, but the general parameters seemed to be more uniform than they had been.

These remarks are based on a superficial visit, and I put them forward only because they may serve as markers for those who make subsequent studies. For them, it is clear that no study of the Indo-Fijian diaspora could omit the transnational links that have grown up - that is, a study of the diaspora of the diaspora. In what ways do the people in this secondary diaspora govern or influence actions and motivations in Fiji; and what links have grown up within this diaspora itself? For example, when visiting the son of one of my Moto friends who was living in Sydney, I found that his wife went annually to Seattle to babysit her grandsons whilst their parents went on vacation. Many of my interlocutors in Fiji said that they were hoping, or planning, to leave the country, whose Indo-Fijian population percentage has already diminished from a peak of $50 \%$ - when there were fears of its 'swamping' the native Fijian population (Indians in Fiji, 60) - to some 36\%. Might this secondary diaspora come to be larger than the primary diaspora, and with what social and economic implications for each?

I end with a few observations of a more personal nature, but which may be relevant for other Rip van Winkles. These deal with questions revolving around memory and distance. To begin, I must again mention that I often could not believe where I was: was I really in Fiji again? This feeling occurred not only during those first days in Suva, but also at other times during my stay. Why did this intimation of unreality persist? I think it was for two reasons. One was that Fiji was for me, a Londoner, literally at the other side of the world; and the other was that my memories of 1950 overlay the present and thereby rendered both 'unreal' in different ways.

Take, first, my perception of distance. In 1950, it had taken us nearly five weeks to go by ship from London to Sydney, then taking another ship for 3 days to Auckland and finally a plane to Nadi. Sea travel at that time was all about voyages, by that I mean travel to a destination for a purpose. (Nowadays sea travel consists mainly of cruises, but these are not voyages: they end at the 
same place as they start and the destination is not the reason for the travel.) The present air journey from London to Suva, though long by present standards, was for me an 'interlude' rather than a 'journey', though I read into this longhaul flight the scale of distance that had operated in the days of my voyages. The unreality that I felt from time to time was thus partly an overlay on the present reality of my memory of long voyages. But partly it worked in the opposite direction. The growing convergence of clothing (jeans, trainers), diet (Indian food now one of the defaults for restaurants in both London and Suva), traffic problems etc. provided an overlay of sameness on my memory of distancerelated difference and thereby created that unreality.

How were the various perceptions of what I was seeing and hearing influenced, mediated, by my memory? Elsewhere ('Anthropological Memories') I considered the role of memory in both anthropological research and subsequent writing up, distinguishing several types of revisit, and the different kinds of memory identified by writers on the subject. As an example of how the anthropologist might make use of memory, I cited my revisit in 1983 to the Indian village I had studied in 1954. Before going I identified two topics which I wished to study. When I tried to call up memories about the first-caste and commensal relations - nothing emerged. I suggested that this was because I had done much work on this topic during the intervening time, i.e. that there had been what can be called 'retroactive inhibition'; that is, the intrusion of my detailed analysis (Caste and Kinship in Central India, 1960) on the subject on my memory. But the other topic, the 'quality of life', was not subject to this inhibition and thus called up memories which my subsequent visit confirmed to be relevant in interpreting the changed situation ('Anthropological Memories', 213-14).

Had I been going to Fiji in 2010 to do research, I would have tried to conjure up memories, later to see what contribution they made to what I found. In the event, my visit can be seen as the hors d'oeuvre for a meal which I did not then stay to eat. Some idea of what these memories would have been can be seen from those which came to me when I was actually in Fiji. The views of the settlements as 'overgrown', the interiors of houses as 'over furnished', the impression of a convergence of life style: each of these implied a previous memory. The first memory which struck me when coming to Moto and Coqeloa was of far-off homesteads. The actual distance might not have been great, but visits in 1950 had often involved a hot and tiring walk on dusty or muddy paths, sometimes having had to ford rushing streams. Indeed, much of my time in both settlements had been spent in going to homesteads, often to find them empty and my long walk wasted. Unsurprisingly, this memory accompanied my progress in Chris's 4WD - the homesteads seemed to be so close to each other! I had no Proustian 'pure memory' of Fiji as I describe for the Indian village 
('Anthropological Memories', 215), but I believe that this may be because this could only have come to me during the years 1951-4, before my long stay in India overwrote such delicate traces.

All this is to say that memory would have been a significant constituent of a restudy in 2010, and that it could have been thus harnessed. In fact, my memories enriched my visit as well as providing an emotional bridge to the people I met. With them I recalled events which we had in common, and unlocked to a small extent the re-creation of the ties which I had had in 1950.

My writings on Fiji have finished with contrasting conclusions. I ended my first study in 1950 by saying: 'it was a Gujarati-born in one of the settlements who advocated closer ties with India. ... His Fiji-born hearers could not believe that they would ever have to leave Fiji. They felt themselves to be Fiji Indians, proud of their heritage, but equally proud of their place in the new society described in this book' (Peasants 1961: 193). By 1963, I had somewhat tempered this view, and my concluding paragraphs outlined two possible paths in the future: one in which 'the present communal separation will continue, with chronic tension and later, perhaps, periodic outbreaks of violence'; and the other foreseeing 'a drawing together of the communities ... through the positive efforts of leaders to cooperate with each other', and I ended by saying that 'whatever course is followed both faith and perseverance will be needed in the uncertain future which lies before Fiji' (Indians in Fiji, 135). After my visit in 1971 I concluded that the settlements I knew best had seen 'decades ... of adaptation to change, and one can reasonably hope that this will continue' (Peasants 1973: 223), a more anodyne statement than either of the two preceding ones.

What would I say after the present brief visit? I think that my conclusion of 1950 has been overtaken by events. Of the two paths suggested in the conclusion of 1963, it is perhaps the one of separation and tension which has been followed, yet not exclusively. As to the conclusion of 1973, Indo-Fijians are continuing to adapt to the changing situation, even if this means in part a continuing emigration, leaving the community a diminishing percentage of the total population with all that this implies. About the future I make no prediction. For, in my late eighties, I can hardly hope to return again to assess its validity, in short to assume yet again the role of Rip van Winkle in Fiji.

Adrian Mayer was a Research Scholar and then a Research Fellow at The Australian National University from 1950 to 1956, gaining his PhD at the London School of Economics and Political Science. Thereafter he was a member of the School of Oriental and African Studies (SOAS), University of London, retiring as Professor of Asian Anthropology in 1985. He was President of the Royal Anthropological Institute and holds its Rivers Memorial Medal, and is now an Honorary Fellow of SOAS. 


\section{Acknowledgements}

I would like to acknowledge the welcome and help I received during this visit from too many friends old and new to mention individually, both in the three settlements and in the University of the South Pacific, but particularly from Chris Gregory, who suggested this visit and who accompanied me throughout as my companion and amanuensis, and who with Judith extended to me such memorable hospitality, as well as their helpful comments on a draft of this article.

\section{Works Cited}

Mayer, A.C. 'Anthropological memories.' Man (NS) 24.2 (1989): 203-18.

-. Caste and Kinship in Central India. London: Routledge \& Kegan Paul, 1960.

-. Indians in Fiji. London: Oxford UP, 1963.

-. Peasants in the Pacific. London: Routledge \& Kegan Paul, 1961.

-. Peasants in the Pacific (2nd enlarged edition). London: Routledge \& Kegan Paul, 1973. 